\begin{tabular}{|l|l|l|}
\hline \multicolumn{2}{|c|}{ PublisherInfo } \\
\hline \hline PublisherName & $:$ & BioMed Central \\
\hline \hline PublisherLocation & $:$ & London \\
\hline \hline PublisherImprintName & $:$ & BioMed Central \\
\hline \hline
\end{tabular}

\title{
Chromatin control during the cell cycle
}

\begin{tabular}{|l|c|l||}
\hline \multicolumn{2}{|c|}{ ArticleInfo } \\
\hline \hline ArticleID & $:$ & 4479 \\
\hline \hline ArticleDOI & $:$ & $10.1186 /$ gb-spotlight-20020514-01 \\
\hline \hline ArticleCitationID & $:$ & spotlight-20020514-01 \\
\hline \hline ArticleSequenceNumber & $:$ & 145 \\
\hline \hline ArticleCategory & $:$ & Research news \\
\hline ArticleFirstPage & $:$ & 1 \\
\hline \hline ArticleLastPage & $:$ & 2 \\
\hline \hline & & RegistrationDate : 2002-5-14 \\
\hline ArticleHistory & $:$ & OnlineDate \\
\hline \hline ArticleCopyright & $:$ & BioMed Central Ltd2002-5-14 \\
\hline \hline ArticleGrants & $:$ & \\
\hline \hline ArticleContext & $:$ & 130593311 \\
\hline \hline
\end{tabular}




\section{Jonathan B Weitzman}

Email: jonathanweitzman@hotmail.com

Maintaining cells in the quiescent G0 phase of the cell division cycle is achieved by suppressing the expression of genes required for cell-cycle progression. In the May 10 Science, Hidesato Ogawa and colleagues at the Dana-Farber Cancer Institute in Boston describe a repressive mechanism in quiescent cells involving the E2F-6 transcription factor (Science 2002, 296:1132-1136). They immunopurified protein complexes that include E2F-6 from human cells and analysed co-purifying protein bands by mass spectrometry. They detected the DP-1, Mga and Max transcription factors and showed that the E2F-6 complex can bind to E2F- and Myc-binding sites on DNA; they also found two associated histone methyltransferase enzymes. In addition, Ogawa et al.detected the HP1 $\gamma$ protein that binds to methylated lysine 9 residues in the tails of histone proteins. Finally, they also found evidence for Polycomb-grouplike, ring-finger proteins in the same complex. The authors propose that E2F- and Myc-regulated genes are repressed in quiescent cells by E2F-6 and recruitment of a complex that modifies chromatin structure.

\section{References}

1. Science, [http://www.sciencemag.org]

2. Dana-Farber Cancer Institute, [http://www.dfci.harvard.edu]

3. Unusual proliferation arrest and transcriptional control properties of a newly discovered E2F family member, E2F-6. 